\title{
Bacterial Contaminants and Antibiogram of Ghana paper currency notes in circulation and its associated Health risks in Asante-Mampong, Ghana
}

Denis Dekugmen Yar (PhD) ( $\sim$ dekugmen@gmail.com)

Department of Science Education, Faculty of Science and Environment Education, College of Agriculture Education, Asante-Mampong, University of Education Winneba, Ghana https://orcid.org/0000-00033079-1432

\section{Research Article}

Keywords: Ghanaian currency, Asante-Mampong, Bacterial, Antibiogram, health risk

Posted Date: September 16th, 2020

DOI: https://doi.org/10.21203/rs.3.rs-77708/v1

License: (a) (i) This work is licensed under a Creative Commons Attribution 4.0 International License.

Read Full License 


\title{
Bacterial Contaminants and Antibiogram of Ghana paper currency notes in circulation
}

\author{
and its associated Health risks in Asante-Mampong, Ghana
}

Denis Dekugmen Yar (Ph.D.)

\section{Author affiliation:}

Department of Science Education, Faculty of Science and Environment Education, College of Agriculture Education, Asante-Mampong, University of Education Winneba, Ghana

\section{Corresponding Author:}

Phone Number: +233(0) 243236810; ddyar@uew.edu.gh / dekugmen@ gmail.com

\begin{abstract}
Transmission of pathogens through currency notes has become very relevant in today's world due to Covid-19 pandemic. This study profiled microbial flora and their antibiotics activities from Ghana paper currency $(\mathrm{GH} \phi)$ notes in circulation in Mampong Municipal of Ashanti Region, Ghana. The study employed a cross-sectional design to assess bacterial contaminants and their antibiotics activities from January to May 2019. A total of $70 \mathrm{GH} \not$ notes consisting of 15 each of GHC1, GHC2, and GHC5; 10 each of GHC10 and GHC20 and 5 of GHC50 were randomly sampled from persons at different shops, canteens and commercial drivers. The surfaces of each $\mathrm{GH} \varnothing$ note were gently swabbed and a ten-fold serial dilutions made inoculated on Plate Count Agar (PCA), MacConkey Agar, Mannitol Salt Agar and Desoxycholate Citrate Agar. The study used appropriate laboratory and biochemical tests for bacteria identification. SPSS-IBM version 16.0 was used to analyze the data. Of the $70 \mathrm{GH} \phi$ notes studied, $97.1 \%$ were contaminated with one or more bacterial isolates. Mean counts on PCA ranged between $3.2 \mathrm{cfu} / \mathrm{ml} \mathrm{x} 10^{5}$ and 4.7 $\mathrm{cfu} / \mathrm{ml} \times 10^{5}$ on $\mathrm{GH} \phi$ notes. Of 124 bacteria isolated; 34(27.4\%), 30(24.2\%), 22(17.7\%), $17(13.7 \%)$, and $8(6.5 \%)$ were from $\mathrm{GH} \phi 1, \mathrm{GH} \phi 2, \mathrm{GH} \phi 10, \mathrm{GH} \phi 5, \mathrm{GH} \phi 20$ and $\mathrm{GH} \phi 50$ respectively [p<0.05]. Bacterial isolates were; Escherichia coli $(28.23 \%)$, Staphylococcus auerus (16.94\%), Coagulase-negative Staphylococcus (16.13\%), Klebsiella species (11.29\%), Salmonella species (9.68\%), Shigella species (8.87\%), Pseudomonas aeruginosa (5.65\%), and Proteus species (3.23\%). GHф notes had 25.81\%, 20.16\%, 19.35\%, $17.74 \%$ and $16.94 \%$ from meat shops, commercial drivers, canteens, grocery shops, and vegetable shops in that order. All bacteria were $100 \%$ resistant to erythromycin, $87.5 \%$ to tetracycline, chloramphenicol, and cotrimoxazole; $75 \%$ to vancomycin while $87.50 \%$ sensitive to amikacin. The $\mathrm{GH} \phi$ notes were heavily colonized with potential pathogens which are resistant to most commonly used antibiotics and could pose health threat to users during commercial transactions.
\end{abstract}

Key Words: Ghanaian currency, Asante-Mampong, Bacterial, Antibiogram, health risk. 


\subsection{Introduction}

Globally, paper currency notes are widely used to exchange for goods and services [1-3]. Users often contaminate these notes with several microflora including viruses, fungi, protozoan and bacteria via unhygienic conditions and habits $[1,4-6]$. Some of these practices and habits include nose picking, coughing and sneezing on palms , applying saliva on fingers to aid notes counting, improper hands washing after using toilets, and storage of paper notes on contaminated surfaces $[3,7]$.

Historically, money was strongly linked to fatal infections like the 'Black Death' or bubonic and pneumonic plaque pandemics [8-10]. Currency notes therefore serve as fomite and vehicle for the transfer of microflora from one user to another [11-13]. Infection with pathogens through contact with fomite is widespread and more serious in the era of Covid-19 pandemic. Individuals get infected by touching objects or surfaces contaminated with pathogenic microbes while touching the eyes, nose or mouth [14].

Infections caused by microflorae on currency notes are largely bacterial and many of them defied treatment with antibiotics [15-19]. Resistance to antibiotic treatment by some of these bacteria had claimed millions of lives despite huge investments and efforts to decrease the predicaments [20, 21]. This has a dire global health consequences and is incumbent to check the disease transmission and antibiotic resistance via fomite [12, 22]. Global surveillance showed there is widespread antibiotics resistance $[18,23,24]$ including drug-resistant Streptococcus pneumonae, vancomycin-resistant Staphylococcus aureus, methicillin-resistant Staphylococcus aureus, multidrug-resistant Pseudomonas aeruginosa, etc. [17, 25, 26].

In Ghana, Mobile money (M-money) and Electronic commerce (E-commerce) payments for goods and services in the informal sector is very low $[27,28]$. There is, however, a gradual use $(4.8 \%)$ 
of M-money and E-commerce due to some perceived risk issues and service charges [29]. Other studies showed that majority of participants preferred cash instead of M-money to pay for goods and services $[30,31]$. The Ghana paper currency $(\mathrm{GH} \phi)$ notes are constantly passed on from one user to another with dirty hands, squeezed, mutilated, and kept on contaminated surfaces [32].

Earlier studies also reported that the $\mathrm{GH} \phi$ notes were heavily colonized by microflorae $[1,33]$ with some being pathogenic (Mensah et al, 2002). These notes therefore carried pathogenic bacteria that can infect handlers [34] and are resistant to antibiotics [35]. In Ghana, money is the most often and widely passed item from one user to another for commercial transactions. Meanwhile, pathogenic bacteria colonized our hands although adherence to effective hand washing is not observed by most Ghanaians[36]. Adherence to Covid-19 protocols among Ghanaians is thus fraud with some difficulties. The mantra "to wash your hands regularly with soap and water or clean with alcohol-based hand rub" cannot be overemphasize [14].

Infections with pathogens via faecal oral route from fomites are rampant [37]. There is, however, poor adherence to effective hand washing among many food vendors in Ghana[38] although cooked food is sometime served with bare hands[39]; thus putting customers at risk of foodborne infections[40]. There are several studies conducted on microbial contamination on GHф notes mainly in major cities in Ghana. There is however paucity of empirical data on bacteria and their antibiotic profile on $\mathrm{GH} \phi$ notes in peri-urban Ghana. This study examined the microbial flora and their antibiotic activities from the Ghana paper currency notes. 


\subsection{Methodology}

\subsection{Study Area}

The study area was in Mampong Municipal of Ashanti Region, Ghana. It is one of the twentyseven (27) Administrative Districts located north of the region, and shares boundaries with Atebubu-Amantin Municipal, Sekyere East, Afigya-Sekyere, and Ejura- Sekyeredumasi to the north, east, south, and west [41]. The Municipal is within longitudes 0.05 degrees and 1.30 degrees west and latitudes 6.55 degrees and 7.30 degrees north, covering a total land area of $2346 \mathrm{~km}^{2}$. The Municipal capital, Mampong is about $57 \mathrm{~km}$ from the regional capital, Kumasi. The Municipal population is about 88,051 , out of which 42,653 are males and 45,398 are females. Agriculture is the main economic activity within the municipal and employs about $67.3 \%$ of the entire labour force. The climate and topography of the area is conducive for agriculture $[42,43]$.

\section{2 Study design}

This study employed descriptive cross-sectional design to assess microflora contamination on Ghana paper currency $(\mathrm{GH} \phi)$ notes and their antibiotic activities in Mampong Municipal from January to May 2019.

\subsection{Sample Size and Sampling}

The currency notes included $\mathrm{GH} \phi 1, \mathrm{GH} \phi 2, \mathrm{GH} \phi 5, \mathrm{GH} \not 10, \mathrm{GH} \phi 20$ and $\mathrm{GH} \phi 50$ which are the most widely circulated denominations. A total of $70 \mathrm{GH} \phi$ notes made up of $15 \mathrm{GH} \phi 1,15 \mathrm{GH} \phi 2,15$ $\mathrm{GH} \phi 5,10 \mathrm{GH} \phi 10,10 \mathrm{GH} \phi 20$ and $5 \mathrm{GH} \phi 50$ were randomly sampled from different sources in Mampong Township. This study sampled only GHф introduced by the Bank of Ghana in 2007. The numbers of each $\mathrm{GH} \phi$ note sampled based on the frequency of usage and volume in circulation. 


\subsection{Sample collection procedures}

The study used aseptic techniques to collect each $\mathrm{GH} \phi$ note into a separate plastic envelope bags and sealed. These notes collected were from grocery shops, canteens, commercial drivers, butchers outlets and vegetable shops. The notes were either obtained by exchanging fresh bank notes for old notes or through a commercial activity. The study used a week to sample each denomination to improve efficiency.

\subsection{Laboratory Methods and Analysis}

\subsubsection{Media Used for culture}

The media used were products of OXOID Limited, Basingstoke Hampshire, England. The study adopted the OXOID standard protocol for media preparation except for Selenite F Broth. The media included Plate Count Agar (PCA), MacConkey Agar (MCA), Mannitol Salt Agar (MSA) and Desoxycholate Citrate Agar (DCA), Simmons Citrate Agar, Triple Sugar Iron Agar (TSI), Selenite Broth and Peptone Water. Reagents were Kovacs and Remel BactiDrop Oxidase. PCA, MCA, DCA, and MSA were media used for total viable count, gram-negative bacteria, Salmonella-Shigella, and for Staphylococcus isolation in that order. Mueller Hinton Agar (MHA) was medium used for antimicrobial susceptibility test.

\subsubsection{Sample processing}

Each $\mathrm{GH} \notin$ note was given a unique identifier. Both surfaces of the note were gently swabbed with a sterile cotton moistened with sterile buffered peptone water (BPW). The swabs in their respective tubes with $1 \mathrm{ml}$ sterile BPW was then vortex to get a uniform suspension. The study made a tenfold serial dilutions of each suspension for cultivation and identification of microbial contaminants. The GHф notes swabbed for the study were later cleaned with MAK SWAB (Alcohol swab). 


\subsubsection{Cultivation and Enumeration}

The study used $0.1 \mathrm{ml}$ of each dilution and inoculated unto the right media and incubated at $37^{\circ} \mathrm{C}$ for 12-48 hours. The culture plates were then examined for growth and morphologic characteristics based on standard microbiological methods. Discrete colonies were sub-cultured on Nutrient Agar for biochemical analysis and for Gram's staining technique [44]. Electronic colony counter was then use to count total viable colonies and the average counts expressed in CFU/ml [44].

\subsubsection{Identification of isolates}

The study identified bacterial isolates using standard microbiological methods [45]. Gram's staining, colony morphology and suitable biochemical tests were methods used to identify bacterial isolates. For gram-positive cocci bacteria with purple round shapes, catalase and coagulase tests differentiated staphylococci (catalase-positive) from streptococci (catalase-negative). Isolates of gram-negative rods on MCA were further grouped into lactose and non-lactose fermenters. These isolates were then inoculated unto TSI, Indole test, citrate test, etc., to aid identification [44].

\section{Salmonella and Shigella species.}

Colonies from samples pre-enriched in Selenite F Broth $\left(\right.$ Difco $\left.^{\mathrm{TM}}\right)$ plated on DCA with pale or colourless colonies with or without black spot in the middle was suggestive of Salmonella while colonies with pink zone, identified Shigella [44].

\section{Staphylococcus species}

Colonies on MSA plates with yellow colonies with halo zone and colonies with pink with reddishpurple zones indicated Staphylococcus aureus and Staphylococcus epidermidis. Coagulase test differentiate between Staphylococcus aureus (coagulase positive) and Staphylococcus epidermidis (Coagulase-negative Staphylococcus[CNS]) [44]. 


\section{Other Gram Negative Isolates}

All gram-negative bacteria from MCA were subsequently inoculated in TSI and incubated. Growth with acidic butt, acidic slant, and gas production without hydrogen sulphide $\left(\mathrm{H}_{2} \mathrm{~S}\right)$ indicated either E coli or Klebsiella species. The two isolates were further identified by Indole and Citrate tests. Red ring formation on the surface of Indole identified $E$ coli. Blue colour change of citrate after incubation confirms Klebsiella species. An acidic butt, acidic slant, and gas production with $\mathrm{H}_{2} \mathrm{~S}$ identified Proteus spp. Alkaline butt, alkaline slant, no gas and $\mathrm{H}_{2} \mathrm{~S}$ production identified Pseudomonas aeruginosa [44].

\subsection{Antibiotic susceptibility testing (AST)}

Agar diffusion technique on Mueller-Hinton agar (Kirby-Bauer modified disc diffusion technique) according to CLSI guidelines [46, 47] determined the antibiotics susceptibility. The inhibition zone standards for antimicrobial susceptibility were from tables of interpretative zone diameters of Clinical and Laboratory Standards Institute [48]. The study tested 10 antibiotic discs of the most commonly used drugs to treat human and animal infections caused by bacteria. These included

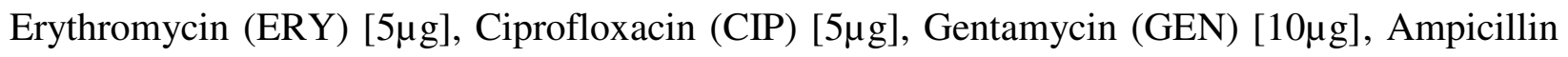
(AMP) $[10 \mu \mathrm{g}]$, Amoxicillin (AMX) $[5 \mu \mathrm{g}]$, Vancomycin (VAN) [30 $\mu \mathrm{g}]$, Tetracycline (TET)

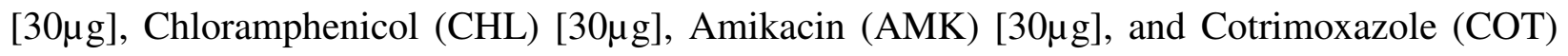
$[25 \mu \mathrm{g}][49,50]$.

\subsection{Statistical Analysis}

Raw data from microbial analysis were then entered into Microsoft excel 2007 spreadsheet and transformed the counts into $\log _{10}$ for normal distribution. The data were later exported into Statistical Package for Social Sciences (SPSS-IBM) version 16.0 software and analyzed using descriptive statistics and presented as tables. The analysis compared sources of currency notes 
using t-test at $95 \%$ confidence interval $(\mathrm{p} \leq 0.05)$ and $(\mathrm{p} \geq 0.05)$ and comparison of means using Tukey-Kramer (Tukey's W) multiple comparison analysis.

\subsection{Ethical consideration}

Formal permission was sought from the Municipal Authorities in Mampong. This study did not collect personal data from study participants. The study therefore obtained only verbal consent and approval from participants before sample collection.

\subsection{Assumptions}

This study assumed that canteens, vegetable shops, butchers outlets, grocery shops and commercial drivers were avenues in which currency notes are often exchanged and passed on from one user to another on daily basis.

\subsection{Results and Discussion}

\subsection{Results}

Out of $70 \mathrm{GH} \notin$ notes examined, 68(97.1\%) had bacteria contaminants. Table 1 shows means total bacterial counts from different denominations on different media. Mean counts ranged from 3.2 $\mathrm{cfu} / \mathrm{ml} \times 10^{5}$ to $4.7 \mathrm{cfu} / \mathrm{ml} \times 10^{5}$ on PCA; $1.7 \mathrm{cfu} / \mathrm{ml} \times 10^{4}$ to $8.2 \mathrm{cfu} / \mathrm{ml} \times 10^{4}$ on DCA; $1.2 \mathrm{cfu} / \mathrm{ml}$ x $10^{5}$ to $2.4 \mathrm{cfu} / \mathrm{ml}$ x $10^{5}$ on MCA and $1.2 \mathrm{cfu} / \mathrm{ml}$ x $10^{5}$ to $2.7 \mathrm{cfu} / \mathrm{ml}$ x $10^{5}$ on MSA.

Table 1. Mean microbial counts on different culture media (cfu/ml)

\begin{tabular}{lllllllll}
\hline $\begin{array}{l}\text { Media } \\
\text { Currency }\end{array}$ & \multicolumn{2}{c}{ PCA (cfu/ml) } & \multicolumn{2}{c}{ DCA(cfu/ml) } & \multicolumn{2}{c}{ MCA(cfu/ml) } & \multicolumn{2}{c}{ MSA(cfu/ml) } \\
\hline $\mathrm{GH} \phi 1$ & $4.7 \times 10^{5}$ & 5.67 & $8.2 \times 10^{4}$ & 4.91 & $1.9 \times 10^{5}$ & 5.28 & $2.7 \times 10^{5}$ & 5.43 \\
$\mathrm{GH} \phi 2$ & $4.2 \times 10^{5}$ & 5.62 & $6.0 \times 10^{4}$ & 4.78 & $1.2 \times 10^{5}$ & 5.08 & $2.4 \times 10^{5}$ & 5.38 \\
$\mathrm{GH} \phi 5$ & $3.8 \times 10^{5}$ & 5.58 & $3.1 \times 10^{4}$ & 4.49 & $1.9 \times 10^{5}$ & 5.27 & $2.2 \times 10^{5}$ & 5.34 \\
$\mathrm{GH} \phi 10$ & $4.1 \times 10^{5}$ & 5.61 & $4.4 \times 10^{4}$ & 4.64 & $2.4 \times 10^{5}$ & 5.38 & $2.1 \times 10^{5}$ & 5.32 \\
$\mathrm{GH} \phi 20$ & $4.0 \times 10^{5}$ & 5.6 & $1.4 \times 10^{4}$ & 4.15 & $2.0 \times 10^{5}$ & 5.30 & $2.0 \times 10^{5}$ & 5.30 \\
$\mathrm{GH} \phi 50$ & $3.2 \times 10^{5}$ & 5.51 & $1.7 \times 10^{4}$ & 4.23 & $1.5 \times 10^{5}$ & 5.18 & $1.2 \times 10^{5}$ & 5.08 \\
\hline
\end{tabular}

Key: PCA, DCA, MCA \& MSA are Plate Count Agar, Desoxycholate Citrate Agar, MacConkey Agar \& Mannitol Salt Agar. 
Table 2 shows distribution of bacteria isolated from five different sources. Out of 124 bacteria isolated, meat shops had $32(25.8 \%), 25(20.2 \%)$ among commercial drivers, 24(19.4\%) canteens, 22(17.7\%) grocery shops and 21(16.9) vegetable shops. Isolates were Escherichia coli (28.2\%), Staphylococcus auerus (16.9\%), CNS (16.9\%), Klebsiella species (11.3\%), Salmonella species (9.7\%), Shigella species (8.9\%), Pseudomonas aeruginosa (5.7\%), and Proteus species (3.2\%).

Table 2. Distribution of bacterial isolates according to sources of currency notes

\begin{tabular}{lllllll}
\hline $\begin{array}{l}\text { Currency Note Sources } \\
\text { Bacterial Isolates }\end{array}$ & $\begin{array}{l}\text { Grocery } \\
\text { shops }\end{array}$ & $\begin{array}{l}\text { Meat } \\
\text { shops }\end{array}$ & $\begin{array}{l}\text { Vegetable } \\
\text { shops }\end{array}$ & Drivers & Canteens & Total (\%) \\
\hline Escherichia coli & 7 & 8 & 7 & 7 & 6 & $35(28.2)$ \\
Salmonella species & 2 & 3 & 2 & 2 & 3 & $12(9.7)$ \\
Shigella species & 2 & 4 & 1 & 1 & 3 & $11(8.9)$ \\
Proteus species & 0 & 2 & 0 & 1 & 1 & $4(3.2)$ \\
Pseudomonas aeruginosa & 1 & 2 & 1 & 2 & 1 & $7(5.7)$ \\
Klebsiella species & 2 & 2 & 2 & 3 & 3 & $12(9.7)$ \\
CN-Staphylococcus & 3 & 5 & 4 & 5 & 4 & $21(16.9)$ \\
Staphylococcus aureus & 5 & 6 & 4 & 4 & 3 & $22(17.7)$ \\
Total (\%) & $22(17.7)$ & $32(25.8)$ & $21(16.9)$ & $25(20.2)$ & $24(19.4)$ & $124(100)$ \\
\hline
\end{tabular}

Table 3 shows prevalence of bacterial isolates on different $\mathrm{GH} \not$ denominations. Out of 124 isolates, 34(27.4\%), 30(24.2\%), 22(17.7\%), 17(13.7\%), and 8(6.5\%) were from $\mathrm{GH} \phi 1, \mathrm{GH} \phi 2$, $\mathrm{GH} \phi 10, \mathrm{GH} \phi 5, \mathrm{GH} \phi 20$ and $\mathrm{GH} \phi 50$ respectively $(\mathrm{p}<0.05)$.

Table 3. Distribution of bacterial isolates based to the currency notes denomination

\begin{tabular}{llllllll}
\hline Isolated bacteria & GHф1 & GHф2 & GHф5 & GHф10 & GHф20 & GHф50 & Total (\%) \\
\hline Proteus species & 0 & 2 & 1 & 1 & 0 & 0 & $4(3.2)$ \\
Pseudomonas aeruginosa & 1 & 2 & 1 & 2 & 1 & 0 & $7(5.7)$ \\
Shigella species & 4 & 3 & 2 & 2 & 0 & 0 & $11(8.9)$ \\
Salmonella species & 5 & 4 & 0 & 2 & 1 & 0 & $12(9.7)$ \\
Klebsiella species & 4 & 4 & 1 & 2 & 1 & 0 & $12(9.7)$ \\
CN staphylococcus & 4 & 4 & 3 & 4 & 3 & 3 & $21(16.9)$ \\
Staphylococcus aureus & 7 & 3 & 4 & 5 & 2 & 1 & $22(17.2)$ \\
Escherichia coli & 9 & 8 & 5 & 4 & 5 & 4 & $35(28.2)$ \\
Total (\%) & $34(27.4)$ & $30(24.2)$ & $17(13.7)$ & $22(17.7)$ & $13(10.5)$ & $8(6.5)$ & $124(100)$ \\
\hline
\end{tabular}


Table 4 shows antimicrobial susceptibility patterns of bacteria isolated. All bacteria were $100 \%$ resistant to erythromycin, $87.5 \%$ to tetracycline, chloramphenicol, and cotrimoxazole, $75 \%$ resistant to vancomycin, $62.5 \%$ to ciprofloxacin and ampicillin, $50.0 \%$ to amoxicillin and ampicillin while $87.50 \%$ sensitive to amikacin.

Table 4. Antibiotic sensitivity patterns of bacterial isolates from Ghanaian currency paper notes

\begin{tabular}{lllllllllll}
\hline Isolated bacteria & ERY & CIP & GEN & AMP & AMX & VAN & TET & CHL & AMK & COT \\
\hline Escherichia coli & $\mathrm{R}$ & $\mathrm{R}$ & $\mathrm{R}$ & $\mathrm{S}$ & $\mathrm{R}$ & $\mathrm{I}$ & $\mathrm{R}$ & $\mathrm{R}$ & $\mathrm{S}$ & $\mathrm{R}$ \\
Salmonella species & $\mathrm{R}$ & $\mathrm{R}$ & $\mathrm{R}$ & $\mathrm{S}$ & $\mathrm{S}$ & $\mathrm{S}$ & $\mathrm{R}$ & $\mathrm{R}$ & $\mathrm{S}$ & $\mathrm{R}$ \\
Shigella species & $\mathrm{R}$ & $\mathrm{R}$ & $\mathrm{S}$ & $\mathrm{R}$ & $\mathrm{R}$ & $\mathrm{R}$ & $\mathrm{R}$ & $\mathrm{R}$ & $\mathrm{S}$ & $\mathrm{R}$ \\
Proteus species & $\mathrm{R}$ & $\mathrm{R}$ & $\mathrm{S}$ & $\mathrm{R}$ & $\mathrm{S}$ & $\mathrm{R}$ & $\mathrm{R}$ & $\mathrm{S}$ & $\mathrm{S}$ & $\mathrm{R}$ \\
Pseudomonas aeruginosa & $\mathrm{R}$ & $\mathrm{S}$ & $\mathrm{R}$ & $\mathrm{R}$ & $\mathrm{S}$ & $\mathrm{R}$ & $\mathrm{R}$ & $\mathrm{R}$ & $\mathrm{I}$ & $\mathrm{R}$ \\
Klebsiella species & $\mathrm{R}$ & $\mathrm{S}$ & $\mathrm{R}$ & $\mathrm{S}$ & $\mathrm{S}$ & $\mathrm{R}$ & $\mathrm{I}$ & $\mathrm{R}$ & $\mathrm{S}$ & $\mathrm{R}$ \\
CN- staphylococcus & $\mathrm{R}$ & $\mathrm{R}$ & $\mathrm{S}$ & $\mathrm{R}$ & $\mathrm{R}$ & $\mathrm{R}$ & $\mathrm{R}$ & $\mathrm{R}$ & $\mathrm{S}$ & $\mathrm{R}$ \\
Staphylococcus aureus & $\mathrm{R}$ & $\mathrm{S}$ & $\mathrm{S}$ & $\mathrm{R}$ & $\mathrm{R}$ & $\mathrm{R}$ & $\mathrm{R}$ & $\mathrm{R}$ & $\mathrm{S}$ & $\mathrm{S}$ \\
\hline \% that are resistant(R) & 100 & 62.5 & 50.0 & 62.5 & 50.0 & 75.0 & 87.5 & 87.5 & 0.0 & 87.5 \\
\% that are susceptible(S) & 0.00 & 37.5 & 50.0 & 37.5 & 50.0 & 12.5 & 0.0 & 12.5 & 87.5 & 12.5 \\
\%that are intermediate(I) & 0.00 & 0.0 & 0.0 & 0.0 & 0.0 & 12.5 & 12.5 & 0.0 & 12.5 & 0.0 \\
\hline
\end{tabular}

Key: ERY- erythromycin, CIP-ciprofloxacin, GEN-gentamicin, AMP-ampicillin, AMXAmoxicillin, VAN-vancomycin, TET-tetracycline, CHL-chloramphenicol, AMK-amikacin \& COT-cotrimoxazole.

\subsection{Discussion}

In this study, nearly all GHф notes sampled had bacterial contaminants. This finding was very similar to earlier studies conducted in Ghana [51, 52], Saudi Arabia [53], and United States of America [54]. Similar findings were also recorded on Iraqi currency [55], South African banknotes [56], Nepal banknotes [57] and Nigerian banknotes [58]. GH $\not$ notes are largely used to exchange for goods and services on cash basis in the country $[30,31]$ with limited use of M-Money and ECommence [27, 28]. The low usage of M-Money and E-Commence could contribute to the high microbial contamination of the $\mathrm{GH} \not$ notes.

This study reported high mean bacteria loads on GHф notes than similar studies conducted in Ghana [35, 52] and akin to earlier studies in Nigeria [15, 58, 59]. Other studies elsewhere reported 
high microbial loads on different currency notes that agreed with finding in this study [60-62]. This study also reported mean counts for coliforms, Staphylococcus species, and ShigellaSalmonella species on GHф notes much higher than a similar study on the Nigeria naira [59] and other currencies [60-62]. The high bacterial load in this study could be linked to the rampant abused of the $\mathrm{GH} \not$ notes especially the lower denominations which are often squeezed, mutilated, mishandled and kept in unhygienic surfaces.

The findings in this study further revealed that, $\mathrm{GH} \phi$ notes of lower denominations were significantly more contaminated than higher notes confirming earlier studies in Ghana and Nigeria [35, 63, 64]. Ghanaians are notorious at abusing and mishandling $\mathrm{GH} \not$ notes with carless abundance and impunity. There seems to be little regards for the lower denominations and this may be linked to the high bacterial loads on the lower $\mathrm{GH} \not$ notes. Moreover, lower $\mathrm{GH} \phi$ notes are frequently passed on from one user to another in diverse economic and social activities with unclean hands further contributing to the high contaminations[64]. Meanwhile, higher GH $\phi$ notes are often saved in banks, more respected and less frequently handled.

This study also reported eight different bacteria species of which S. auerus was predominant on $\mathrm{GH} \not$ notes. Previous studies recovered similar microbes from $\mathrm{GH} \not \subset$ notes of which CNS was most prevalence $[35,63,64]$. Money is the most handled and circulated item among the public making it prone to microbial contamination with a potential to cause diseases to handlers. In this study, Escherichia coli, Salmonella spp, and Shigella spp were pathogens recovered from GHф [65]. These faecal bacteria on $\mathrm{GH} \phi$ is an indication of lack of effective hand washing after using washrooms [36, 66] and unhygienic practices among users [67].

In this study, there was no link between sources of $\mathrm{GH} \notin$ notes and microbial contamination. $\mathrm{GH} \phi$ notes collected from meat shops, commercial drivers and canteens recorded the highest numbers 
of bacterial isolates. GH $\varnothing$ notes from meat shops were likely to be contaminated with blood which is a good medium for bacteria growth [44, 64]. Commercial drivers often exchanged notes with passengers with unclean hands increasing the rate of contamination [1, 4, 5, 39]. Canteens are often patronized by many people where $\mathrm{GH} \phi$ notes are exchanged in minutes from one user to another with dirty hands [68]. GHф notes from canteens had all species of bacteria isolated, an indication that food vendors hands possibly carried faecal coliforms and could lead to foodborne illnesses $[39,69,70]$. Customers with unclean hands could further increase their risk of contracting food related diseases [71]. The prevalence of bacterial contamination was least on GH $\varnothing$ notes collected from vegetable shops although vegetables are known to carry microbes [72, 73].

This study revealed that most bacteria isolated from the $\mathrm{GH} \varnothing$ notes were resistant to the widely used antibiotics $[18,74]$. This has public health implications since these bacteria are pathogens that could easily infect users and would fail treatment with these antibiotics[75]. Moreover, many of these isolates were resistant to multiple antibiotics which is a threat to public health in Ghana[76]. However, Amikacin was the most effective antibiotic against these bacterial isolates on the GHф notes. An earlier study reported similar findings in Ghana [51] and other parts of the world [77]. There is increasing threat of antibiotic resistance due to excessive usage without prescriptions from a pharmacist $[78,79]$.

This study has demonstrated that the GH $\varnothing$ notes are heavily contaminated with potential bacterial isolates that are highly resistant to most widely used antibiotics and is a threat to public health. The $\mathrm{GH} \phi$ notes are overly abused with dirty and unhygienic hands contaminating them with pathogenic bacteria with the potential of infecting handlers. It is highly recommended that ECommerce and E-Money should be strongly promoted to save the GHф notes from abused and 
deterioration and the users from harm. The wake of Covid-19 is a testimony for the need to limit or avoid directly handling currency notes for the public good.

\subsection{Limitation of the Study}

The study met some difficulties obtaining GHф notes from the sources. The research assistants bought goods from shops to get the required denominations for the study. Some sources also suspected the team of fraud and trading in fake currencies and were very reluctant.

\subsection{Conclusion and Recommendation}

This study has demonstrated that the GHф notes are heavily contaminated with potential pathogenic bacteria that are highly resistant to the most widely used antibiotics and is a threat to public health. The use of E-Commerce and E-Money is commendable to use for goods and services to minimize the abuse and deterioration of the $\mathrm{GH} \phi$ notes.

\section{Competing interests}

The author has no any potential conflicts of interest.

\section{Author contribution}

DDY conceived and designed the study, drafted the manuscript and critically reviewed it.

\section{Acknowledgement}

I thank Nyarko Simon who helped in the sample collection and laboratory analysis together with Mr. Kwame Adepa, the Department laboratory Technician and Mr. Albert Baffour Awuah, a Teaching Assistant at the Department of Science Education.

\section{Funding}

This laboratory analysis had support by the Faculty of Science and Environment Education and the author. The author is solely responsible for the content and does not represent the official views of the Faculty of Science and Environment Education, University of Education, Winneba 


\section{REFERENCES}

1. Alemu, A., Microbial contamination of currency notes and coins in circulation: A potential public health hazard. Biomedicine and Biotechnology, 2014. 2(3): p. 46-53.

2. Ahmed, M.S.U., et al., Evaluation of the microbial contamination of Bangladesh paper currency notes (Taka) in circulation. Advances in biological research, 2010. 4(5): p. 266271.

3. Alabbasy, A.J., A Literature Review on Microbial Contamination of Paper Currency. IJEC, 2019. 18: p. 22.

4. Butt, A. and S. Malik, Microbial and parasitic contamination on circulating Pakistani Currency. Advancements in Life Sciences, 2015. 2(4): p. 150-157.

5. Ejaz, H., A. Javeed, and M. Zubair, Bacterial contamination of Pakistani currency notes from hospital and community sources. Pakistan journal of medical sciences, 2018. 34(5): p. 1225.

6. ICS, W., T. ELY, and S. Nizam, Isolation and identification of microbial contamination of paper currecncy collected from local night markets in Shah Alam, Selangor, Malaysia. International Journal of Medical Toxicology \& Legal Medicine, 2018. 21(3and4): p. 183186.

7. Agarwal, G., et al., Assessment of microbial contamination of Indian currency notes in Mathura City, India: A cross-sectional study. Journal of Advanced Oral Research, 2015. 6(3): p. 43-48.

8. Tolba, O., et al., Survival of epidemic strains of nosocomial-and community-acquired methicillin-resistant Staphylococcus aureus on coins. American journal of infection control, 2007. 35(5): p. 342-346.

9. Bhat, N., et al., An assessment of oral health risk associated with handling of currency notes. International Journal of dental clinics, 2010. 2(3).

10. Tawfeeq, H.M., M.H. Fatah, and A.M. Tofiq, Evaluating the risk of bacterial infections associated with the most handled Iraqi notes in Kalar. Kurdistan Journal of Applied Research, 2019. 4(1): p. 26-30.

11. Asikong, B., et al., Microbial contamination of Nigerian currency: a potential health risk to handlers. Global Journal of Medical Sciences, 2007. 6(1): p. 35-40.

12. Barolia, S. and B. Saini, Microbial Contamination on different Paper Currency in, Jhunjhunu, Rajasthan, India: A. 2018.

13. Hiko, A., et al., Contamination of Ethiopian paper currency notes from various food handlers with E. coli. SpringerPlus, 2016. 5(1): p. 1065.

14. WHO, Information about COVID-19 - World Health Organization - who.int. 2020.

15. Ayandele, A. and S. Adeniyi, Prevalence and antimicrobial resistance pattern of microorganisms isolated from Naira notes in Ogbomoso North, Nigeria. Journal of research in Biology, 2011. 8: p. 587-593.

16. Barolia, S.K., S. Verma, and B.K. Verma, Coliform contamination on different paper currency in Ajmer, Rajasthan, India. Universal Journal of environmental research and technology, 2011. 1(4): p. 552-556.

17. Neel, R., Multidrug resistance of isolates of methicillin resistant Staphylococcus aureus (MRSA) in paper currency notes from restaurants and hotels in Lusaka in Zambia. Int J Pharm Sci, 2012. 5(1): p. 363-366. 
18. Firoozeh, F., et al., Bacterial contamination of Iranian paper currency and their antibiotic resistance patterns. Int J Enteric Pathog, 2017. 5(4): p. 106-110.

19. Musa, F., et al., Bacterial contamination of Nigerian currency notes circulating within selected markets in Kaduna Metropolis. Bayero Journal of Pure and Applied Sciences, 2019. 12(1): p. 366-371.

20. Ventola, C.L., The antibiotic resistance crisis: part 1: causes and threats. Pharmacy and therapeutics, 2015. 40(4): p. 277.

21. Al-Hajj, E.M., et al., Contamination of Currency Notes with Kanamycin Resistant Shigella flexneri. BioRxiv, 2020.

22. Chokshi, A., et al., Global contributors to antibiotic resistance. Journal of global infectious diseases, 2019. 11(1): p. 36.

23. Abdulla, S.M., Isolation and Identification of causative agents from some Iraqi Banknote currency. Ibn AL-Haitham Journal For Pure and Applied Science, 2017. 26(1): p. 75-81.

24. Morehead, M.S. and C. Scarbrough, Emergence of global antibiotic resistance. Primary care: clinics in office practice, 2018. 45(3): p. 467-484.

25. Neel, R., Multidrug resistance of isolates of methicillin resistant Staphylococcus aureus (MRSA) in paper currency notes from meat sellers in Tanga, Tanzania. Int J LifeSc Bt \& Pharm Res, 2012. 1(4): p. 9-13.

26. Sunil, S., et al., Assessment of microbial contamination of indian currency notes in circulation-An In vitro study. Journal of Indian Association of Public Health Dentistry, 2020. 18(2): p. 179.

27. Amoh, S., Mobile Money Services Adoption and Customer Behavioral Intentions in Ghana. 2016, UNIVERSITY OF GHANA, LEGON.

28. Narteh, B., M.A. Mahmoud, and S. Amoh, Customer behavioural intentions towards mobile money services adoption in Ghana. The Service Industries Journal, 2017. 37(7-8): p. 426-447.

29. Amegbe, H., C. Hanu, and A. Nuwasiima, Small-scale individual entrepreneurs (SIEs) and the usage of mobile money (M-money) and mobile commerce (M-commerce) in facilitating business growth in Ghana. Management Science Letters, 2017. 7(8): p. 373-384.

30. Addo, G.A.N., Assessing the Impact and Challenges of Mobile Money A Case Study of University of Ghana. 2019, University of Ghana.

31. Cobla, G.M. and E. Osei-Assibey, Mobile money adoption and spending behaviour: the case of students in Ghana. International Journal of Social Economics, 2018.

32. Mensah, P., et al., Street foods in Accra, Ghana: how safe are they? Bulletin of the World Health Organization, 2002. 80: p. 546-554.

33. Tagoe, D., et al., A study of bacterial contamination of Ghanaian currency notes in circulation. The Internet Journal of Microbiology, 2010. 8(2): p. 1-5.

34. Rocha-Gamez, J., et al., INTERNATIONAL PERSPECTIVES: Microbial Contamination in 20-Peso Banknotes in Monterrey, Mexico. Journal of environmental health, 2012. 75(2): p. 20-23.

35. Feglo, P. and M. Nkansah, Bacterial load on Ghanaian currency notes. African Journal of Microbiology Research, 2010. 4(22): p. 2375-2380.

36. Oppong, T.B., et al., Hand Hygiene Habits of Ghanaian Youths in Accra. International journal of environmental research and public health, 2019. 16(11): p. 1964.

37. Betancur, C.A., et al., Paper currency as fomite for bacteria with human pathogenic potential. Infectio, 2010. 14(2): p. 120-126. 
38. GHARTEY, A.F. and B.K. ANTWI, HAND HYGIENE PRACTICES AMONG STREET FOOD VENDORS. Food and Environment Safety Journal, 2019. 18(2).

39. Laxminarayan, R. and R.R. Chaudhury, Antibiotic resistance in India: drivers and opportunities for action. PLoS medicine, 2016. 13(3): p. e1001974.

40. Addo-Tham, R., et al., Knowledge on food safety and food-handling practices of street food vendors in ejisu-juaben municipality of Ghana. Advances in Public Health, 2020. 2020.

41. Services, G.S., Population \&Housing Census National Analytical Report of Ghana. 2013.

42. Service, G.S., 2010 Population and Housing Census Report. 2014: Ghana Statistical Service.

43. Service, G.S., 2010 Population \& Housing Census Report: Children, adolescents \& young people in Ghana. 2013: Ghana Statistical Service.

44. Cheesbrough, M., District laboratory practice in tropical countries. 2006: Cambridge university press.

45. Forbes, B.A., D.F. Sahm, and A.S. Weissfeld, Bailey \& Scott's diagnostic microbiology. 2007: Mosby.

46. Hsueh, P.-R., et al., Consensus statement on the adherence to Clinical and Laboratory Standards Institute (CLSI) Antimicrobial Susceptibility Testing Guidelines (CLSI-2010 and CLSI-2010-update) for Enterobacteriaceae in clinical microbiology laboratories in Taiwan. Journal of Microbiology, Immunology and Infection, 2010. 43(5): p. 452-455.

47. Humphries, R.M., et al., The continued value of disk diffusion for assessing antimicrobial susceptibility in clinical laboratories: report from the Clinical and Laboratory Standards Institute Methods Development and Standardization Working Group. Journal of clinical microbiology, 2018. 56(8).

48. Hindler, J.F. and J. Stelling, Analysis and presentation of cumulative antibiograms: a new consensus guideline from the Clinical and Laboratory Standards Institute. Clinical infectious diseases, 2007. 44(6): p. 867-873.

49. Hall, J., Antibodies: A Laboratory_Manual. Immunology Today, 1989. 10(11).

50. Humphries, R.M., et al., Multicenter evaluation of colistin broth disk elution and colistin agar test: a report from the Clinical and Laboratory Standards Institute. Journal of clinical microbiology, 2019. 57(11): p. e01269-19.

51. Tagoe, D. and L. Adam, Antibiotic resistant bacterial contamination of the Ghanaian currency note: a potential health problem. Journal of Microbiology and Biotechnology Research, 2017. 1(4): p. 37-44.

52. Dsani, E., et al., Antimicrobial resistance and molecular detection of extended spectrum $\beta$ lactamase producing Escherichia coli isolates from raw meat in Greater Accra region, Ghana. BMC microbiology, 2020. 20(1): p. 1-8.

53. Nasser, L.A. and S. Alwakeel, Bacterial and fungal contamination of Saudi Arabian paper currency and cell phones. Environmental Engineering and Management Journal, 2012. 11(3): p. 72.

54. Pope, T.W.C., et al., Bacterial contamination of paper currency. Southern medical journal, 2002. 95(12): p. 1408-1411.

55. Moosavy, M.-H., et al., Bacterial contamination of Iranian paper currency. Iranian journal of public health, 2013. 42(9): p. 1067. 
56. Igumbor, E., et al., Microbiological analysis of banknotes circulating in the Venda region of Limpopo province, South Africa. South African Journal of Science, 2007. 103(9-10): p. 365-366.

57. Lamichhane, J., et al., Risk of handling paper currency in circulation chances of potential bacterial transmittance. Nepal Journal of Science and Technology, 2009. 10: p. 161-166.

58. Kawo, A., et al., Prevalence and public health implications of the microbial load of abused naira notes. Bayero Journal of Pure and Applied Sciences, 2009. 2(1): p. 52-57.

59. Uko, M.P., et al., Microbial load, prevalence and antibiotics susceptibility of bacteria isolated from Naira notes. Asian Journal of Biotechnology and Bioresource Technology, 2017: p. 1-8.

60. Manohar, P., et al., Bacterial Load and Contamination of Indian Currency Note: Isolation and Transferability Studies of Multi-Drug Resistant Bacteria. Indian Journal of Public Health Research \& Development, 2018. 9(6): p. 97-102.

61. Akond, M.A., et al., Assessment of bacterial contamination of paper currency notes in Bangladesh. ESAIJ, 2015. 10(3): p. 114-120.

62. Girma, G., T. Ketema, and K. Bacha, Microbial load and safety of paper currencies from some food vendors in Jimma Town, Southwest Ethiopia. BMC research notes, 2014. 7(1): p. 843.

63. Stanley, M.C., et al., Microbiological evaluation of naira notes handled by fish sellers in Umuahia metropolis. World Engineering \& Applied Sciences Journal, 2014. 5(2): p. 4452.

64. Anning, A.S., et al., Antibiotic susceptibility pattern of enterobacteriaceae isolated from raw meat and Ghanaian coin currencies at Cape Coast metropolis, Ghana: The public health implication. The Open Microbiology Journal, 2019. 13(1).

65. Anuranjini, C., D. Alex, and K. Reema, BACTERIAL CONTAMINATION OF INDIAN PAPER CURRENCY AND COINS. 2017.

66. Steiner-Asiedu, M., et al., Hand washing practices among school children in Ghana. Current Research Journal of Social Sciences, 2011. 3(4): p. 293-300.

67. Akoachere, J.-F.T.K., et al., Public health implications of contamination of Franc CFA $(X A F)$ circulating in Buea (Cameroon) with drug resistant pathogens. BMC research notes, 2014. 7(1): p. 16.

68. Kunadu, A.P.-H., et al., Food safety knowledge, attitudes and self-reported practices of food handlers in institutional foodservice in Accra, Ghana. Food Control, 2016. 69: p. 324330.

69. Monney, I., D. Agyei, and W. Owusu, Hygienic practices among food vendors in educational institutions in Ghana: the case of Konongo. Foods, 2013. 2(3): p. 282-294.

70. Caniça, M., et al., Antibiotic resistance in foodborne bacteria. Trends in Food Science \& Technology, 2019. 84: p. 41-44.

71. Boadi, K.O. and M. Kuitunen, Childhood diarrheal morbidity in the Accra Metropolitan Area, Ghana: socio-economic, environmental and behavioral risk determinants. Journal of Health \& Population in Developing Countries, 2005. 7(1): p. 15-22.

72. Balali, G.I., et al., Microbial Contamination, an Increasing Threat to the Consumption of Fresh Fruits and Vegetables in Today's World. International Journal of Microbiology, 2020. 2020. 
73. Amissah-Reynolds, P.K., et al., Fresh Vegetables and Ready-to-eat Salads: Sources of Parasitic Zoonoses in Mampong-Ashanti, Ghana. European Journal of Nutrition \& Food Safety, 2020: p. 47-55.

74. Miller, L.G. and B.A. Diep, Colonization, fomites, and virulence: rethinking the pathogenesis of community-associated methicillin-resistant Staphylococcus aureus infection. Clinical Infectious Diseases, 2008. 46(5): p. 752-760.

75. Gajdács, M. and F. Albericio, Antibiotic resistance: from the bench to patients. 2019, Multidisciplinary Digital Publishing Institute.

76. Founou, R.C., L.L. Founou, and S.Y. Essack, Clinical and economic impact of antibiotic resistance in developing countries: A systematic review and meta-analysis. PloS one, 2017. 12(12): p. e0189621.

77. Oluduro, A., et al., Antibiotic resistance and public health perspective of bacterial contamination of Nigerian currency. Advances in Life Science and Technology, 2014. 24: p. 4-9.

78. Ayukekbong, J.A., M. Ntemgwa, and A.N. Atabe, The threat of antimicrobial resistance in developing countries: causes and control strategies. Antimicrobial Resistance \& Infection Control, 2017. 6(1): p. 47.

79. Zaman, S.B., et al., A review on antibiotic resistance: alarm bells are ringing. Cureus, 2017. 9(6). 